Creative commons User License: CC BY-NC-ND

Abstracted by: EBSCOhost, Electronic Journals Service (EJS),

Google Scholar, Directory of Open Access Journals (DOAJ),

Journal Seek, Scientific Commons,

Food and Agricultural Organization (FAO), CABI and Scopus
Journal of Agricultural Extension

Vol. XX (X) XXXXXX, 20XX

ISSN(e): 24086851; ISSN(Print); 1119944X

http://journal.aesonnigeria.org

http://www.ajol.info/index.php/jae

Email: editorinchief@aesonnigeria.org

\title{
Specialisation Preferences and Perceived Motivation in Ecotourism and Wildlife Management Programme at the Federal University of Technology, Akure, Nigeria \\ http://dx.doi.org/10.4314/jae.v20i2.5
}

\section{Ogunjinmi, A. A.}

Department of Ecotourism and Wildlife Management

School of Agriculture and Agricultural technology

Federal University of Technology, Akure, Nigeria

Email: aaoguniinmi@futa.edu.ng

Phone: +2348077428332

\section{Abstract}

This study determined specialisation preferences and perceived motivational factors in ecotourism and wildlife management programme among students in the Department of Ecotourism and Wildlife Management, Federal University of Technology, Akure, Nigeria. A sample of 156 students was randomly drawn from 261 students in the Department. Data were collected with questionnaire while analysis was through independent $t$-test, ANOVA and Pearson's correlation. Results show that $74.4 \%$ of the students preferred ecotourism management while $25.6 \%$ preferred wildlife management. Furthermore, observed mean values of the perceived motivational factors (selfactualisation $=4.20$, job opportunity $=4.08$, field attractiveness $=3.88$, ease of study=3.55, and scholastic achievement=3.93) were lower than reported in previous studies. It is recommended that the departmental curriculum should enhance opportunities for study exchange programme with institutions offering similar programmes overseas and also field practical exposure in all areas of the programme that could bolster students' job opportunities after graduation.

Keywords: Specialisation, preferences, perceived, motivation, programme

\section{Introduction}

Choosing a profession is a significant stage in life and expresses one's personal inclinations (Natan and Becker, 2010). Studies indicate that people choose a career when it is compatible with factors they perceive as significant for an ideal career (Natan and Becker, 2010). According to Meyer et al. (1993), compatibility leads to a 
Creative commons User License: CC BY-NC-ND

Abstracted by: EBSCOhost, Electronic Journals Service (EJS),

Google Scholar, Directory of Open Access Journals (DOAJ),

Journal Seek, Scientific Commons,

Food and Agricultural Organization (FAO), CABI and Scopus
Journal of Agricultural Extension

Vol. XX (X) XXXXXX, 20XX

ISSN(e): 24086851; ISSN(Print); 1119944X

http://journal.aesonnigeria.org

http://www.ajol.info/index.php/jae

Email: editorinchief@aesonnigeria.org

greater commitment to the chosen career, while incompatibility will eventually result in burnout and exit from the profession. Ajzen (1991) theory of planned behaviour, an extension of the Ajzen and Fishbein (1969, 1980) theory of reasoned action support career choice among individuals. According to the theory, human action is guided by three kinds of considerations which include beliefs about the likely outcomes of the behaviour and the evaluations of these outcomes (behaviour beliefs), beliefs about the normative expectations of others and motivation to comply with these expectations (normative beliefs), and beliefs about the perceived power of these factors (control beliefs) (Ajzen, 2006).

The predisposition for a career choice is a composite of intrinsic and extrinsic factors. Among such factors include family socio-economic backgrounds such as income and types of occupations (Zahari et al., 2005), parental influence, family, friends or significant other people of reference (Ajzen, 1991, Amani, 2013), income and future career prospects (Bhat et al., 2012), intentions, self-esteem and ease of employment (Ajzen, 2006, Amani, 2013). Orenuga and Costa (2006) also identified four major motives for the choice of specialisation as interest, prestige, good employment opportunities and regular work hours. Similarly, Wong et al. (2007) found technical and functional competency, general management competency, autonomy/independency and lifestyle, job security and stability, geographic security, entrepreneurial creativity, service and dedication to a cause and pure challenge as the students' motivational factors to choose a career. In the study conducted in Sweden, Hjalager (2003) reported working with people and/or communication, work experience, and the value of the programmes in many trades and industries as the three most important motives for career selection. Dapiawen et al. (2008) report that the primary reason for students' specialisation is 'my own decision'. According to Ugezu and Modekwe (2012) in their studies of medical doctors, 94\% of the respondents who had made a choice of area of specialisation felt their choices were not influenced by peers and classmates.

Disciplines in academia, according to Nzewi (2008) are primarily concerned with the issues of lectures, research and grades earned by students; attention is seldom 
Creative commons User License: CC BY-NC-ND

Abstracted by: EBSCOhost, Electronic Journals Service (EJS),

Google Scholar, Directory of Open Access Journals (DOAJ),

Journal Seek, Scientific Commons,

Food and Agricultural Organization (FAO), CABI and Scopus
Journal of Agricultural Extension

Vol. XX (X) XXXXXX, 20XX

ISSN(e): 24086851; ISSN(Print); 1119944X

http://journal.aesonnigeria.org

http://www.ajol.info/index.php/jae

Email: editorinchief@aesonnigeria.org

directed towards the critical but non-academic human and social backgrounds that discretely impact students' devotion to study, their failures and successes, their career decisions and fulfilment in the field after graduations. Nzewi (2008) further opined that it is of central human concern that academia should stimulate students to aim for attaining job fulfilment in their chosen careers. This is predicated on constant self-reflection and self-assessment that would enable a suitable choice of areas of specialisation within broad disciplines. Many attributes have been thought to be the underlying factors for the selection of the specialisations in the institutions of higher learning, while more and more determinants are coming up due to the dynamic change in the market which needs to be identified (Lovelock, 2007 cited in Wairimu, 2013). As the challenges of environmental sustainability mount, a steady supply of well-trained and highly educated professionals is needed to meet the complex demand of ecotourism and wildlife sectors. Preferences of present day students may reflect ultimate career choices of future ecotourism and wildife management practitioners, which in turn could play an important role in the development of ecotourism and wildlife sectors in Nigeria. Identifying motivational factors in specialisation preferences will facilitate planning and appropriate changes in ecotourism and wildlife management training and curriculum. According to Arnott and Saunders (2008), past studies seldom delve into the purpose-driven choices made by students in the field of their specialisation. It serves as a significant social study to identify why students opt for the academic discipline of specialisation when pursuing university education (Arnott and Saunders, 2008). To spur interest in agriculture, fisheries and natural resources, courses among the youth require crucial inquiry into their personality endowments and motivational reorientations or partly personal value systems vis-à-vis influences of environmental or external structures (Romeo, 2014).

In Nigeria, admission to courses in the universities could either be through Unified Tertiary Matriculation Examination (UTME) conducted by Joint Admission and Matriculation Board (JAMB) and Pre-degree programme administered by the universities for entry into 100 Level or through Direct Entry (DE) admission for holders of advanced certificates such National Diploma (ND), Nigerian Certificate in 
Creative commons User License: CC BY-NC-ND

Abstracted by: EBSCOhost, Electronic Journals Service (EJS),

Google Scholar, Directory of Open Access Journals (DOAJ),

Journal Seek, Scientific Commons,

Food and Agricultural Organization (FAO), CABI and Scopus
Journal of Agricultural Extension

Vol. XX (X) XXXXXX, 20XX

ISSN(e): 24086851; ISSN(Print); 1119944X

http://journal.aesonnigeria.org

http://www.ajol.info/index.php/jae

Email: editorinchief@aesonnigeria.org

Education (NCE), holders of Diploma through Interim Joint Matriculation Board (IJMB), University Diplomas and Higher National Diploma (HND) for entry into 200 Level and 300 Level respectively. Whatever the entry level, all admissions are through JAMB in conjunction with the universities. Each candidate must obtain JAMB form (UTME Form or DE Form) and select a University, a Polytechnic or Mono-technic and a College of Education as well as first and second preferred course of study and also sits for UTME (except DE candidates) and Post UTME conducted by tertiary institutions in Nigeria. For a candidate to qualify to sit for post UTME conducted by the universities, he or she must have scored 180 marks and above while for post UTME conducted by Polytechnic or Mono-Technic and Colleges of Education, the candidate must have scored between 150 and 179 marks. The aggregate scores obtained from UTME and post UTME is used in determining the cut-off marks for admission into any programme in Nigerian tertiary institutions. Candidates that do not qualify for admission into specific courses selected based on low aggregate scores obtained or score below cut-off marks specified by the institutions and are within cut-off marks for other courses are offered admission to such courses regardless of their preferred courses of choice as long as they possess Ordinary Level $(\mathrm{O} / \mathrm{L})$ requirements and sat for relevant UTME subjects for the course(s). Despite these, matriculated students could change from one programme to another within the university based on the rules and guidelines approved by the senate of the university. For example, in the Federal University of Technology, Akure, Nigeria, a student could seek to change his or her academic programme to another within the University due to poor performance or academic withdrawal. In both cases, the student must not have more than four (4) outstanding courses at 100 Level. The application for change of academic programme must, however, be approved by the senate of the university for such students. Any student whose application for change of academic programme is approved is admitted into 200 Level.

Previous studies on motivational factors in specialisation preferences have been conducted in various disciplines (Gjerberg, 2001, Dapiawen et al., 2008, Natan and Becker, 2010, Bhat et al., 2012), however; few studies relating to tourism/ecotourism 
Creative commons User License: CC BY-NC-ND

Abstracted by: EBSCOhost, Electronic Journals Service (EJS),

Google Scholar, Directory of Open Access Journals (DOAJ),

Journal Seek, Scientific Commons,

Food and Agricultural Organization (FAO), CABI and Scopus
Journal of Agricultural Extension

Vol. XX (X) XXXXXX, 20XX

ISSN(e): 24086851; ISSN(Print); 1119944X

http://journal.aesonnigeria.org

http://www.ajol.info/index.php/jae

Email: editorinchief@aesonnigeria.org

have been conducted and as such, limited information is available on specialisation preferences in ecotourism and wildlife management. Among such studies on tourism are Lee et al. (2008), Sibson (2011), and Bamford (2012). The study is aimed at determining specialisation preferences and perceived motivational factors in ecotourism and wildlife management programme at the Federal University of Technology, Akure, Nigeria. The specific objectives of the study were to identify: i) differences in male and female students' preferred areas of specialisation, ii) differences in male and female students' motivational factors, iii) differences in students' motivational factors based on preferred areas of specialisation, iv) differences in motivational factors based on their level of study, and v) relationships between motivational factors and students' preferred areas of specialisation.

\section{Methodology}

\section{The Study Area}

The study area was Federal University of Technology, Akure, Ondo State, Southwest, Nigeria. The state lies between latitudes $5045^{\prime}$ and 7052 'N and longitudes 4020' and 60 05'E. Its land area is about 15,500 square kilometres (UNAAB-IFSERAR, 2010) (Figure 1). The study was conducted in the Department of Ecotourism and Wildlife Management, School of Agriculture and Agricultural Technology, Federal University of Technology, Akure, Nigeria. The Department is the first Department to offer ecotourism management programme in Nigeria and was established in 2007 through the splitting of the Department of Fisheries and Wildlife Management into Ecotourism and Wildlife Management and Fisheries and Aquaculture Technology. However, the Department took off with 45 students in 2008/2009 academic session. 
Creative commons User License: CC BY-NC-ND

Abstracted by: EBSCOhost, Electronic Journals Service (EJS),

Google Scholar, Directory of Open Access Journals (DOAJ),

Journal Seek, Scientific Commons,

Food and Agricultural Organization (FAO), CABI and Scopus
Journal of Agricultural Extension

Vol. XX (X) XXXXXX, 20XX

ISSN(e): 24086851; ISSN(Print); 1119944X

http://journal.aesonnigeria.org

http://www.ajol.info/index.php/jae

Email: editorinchief@aesonnigeria.org

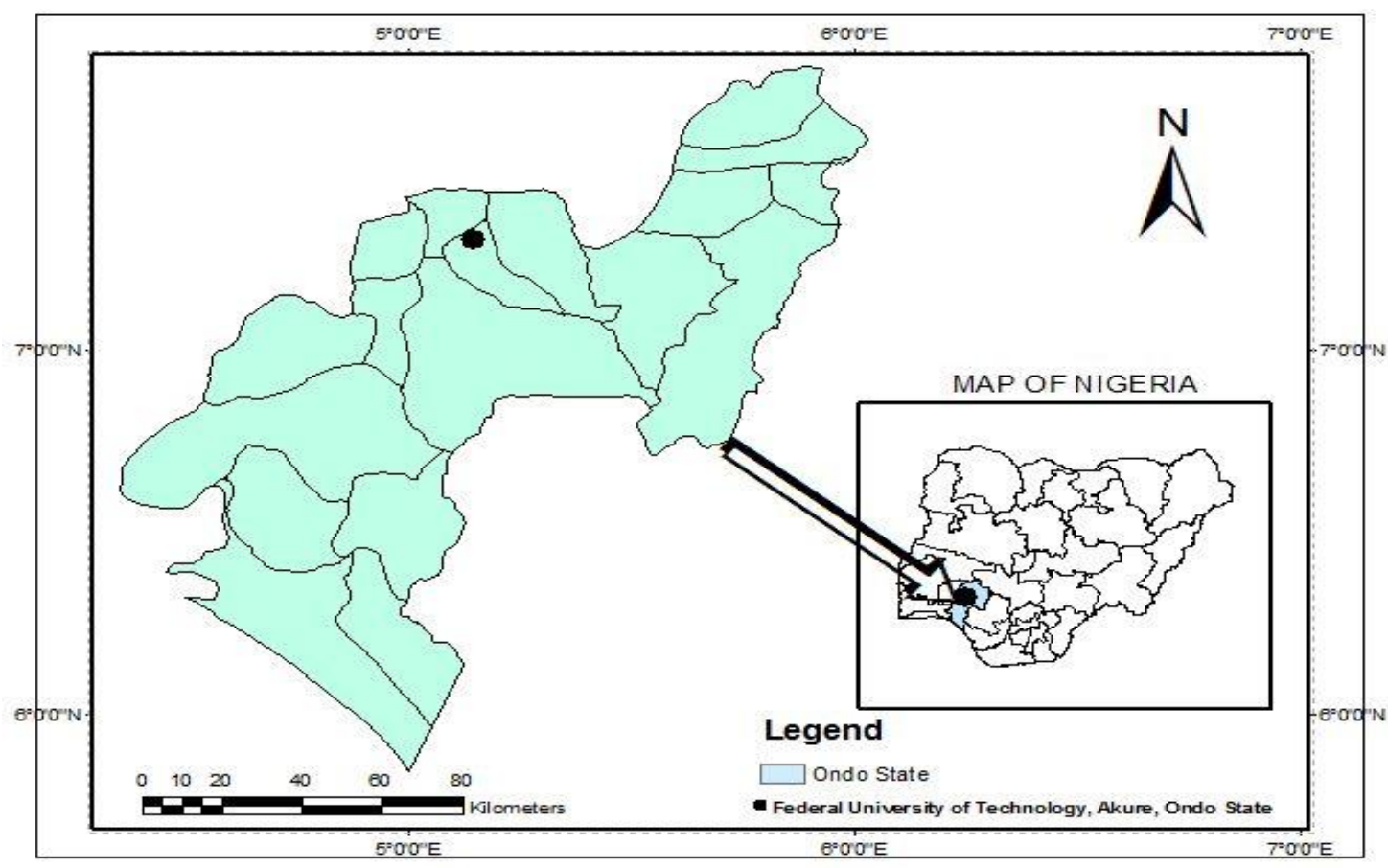

Figure 1: Map of Ondo State, Nigeria showing location of the study area

\section{Population, Sampling, Instrument and Analysis}

The sample size of 156 respondents was determined using Krejcie and Morgan (1970) determination of sample size. As at the time of the study, there were 261 students in the Department comprising 219 undergraduates and 42 graduating students. The sample size was proportionally distributed according to the population of students in each level. Thus, from 37 students in 100 level, 22 students were selected, 28 from 47 in 200 level, 30 from 50 in 300 level, 31 from 52 in 400 level, 20 from 33 in 500 level and 25 were selected from 42 in the graduating class. The respondents in each level were randomly selected from the population. Data were collected using pretested structured questionnaire comprising personal factors such as sex, age, level of study, preferred area of specialisation, and Lee et al. (2008) motivational factors for choosing a hospitality and tourism management programme. Reliability coefficients determination follows Cronbach's (1951). Cronbach's alpha determines the internal consistency or average correlation of items in a survey instrument to gauge its reliability (Santos, 1999). For overall motivation, the reliability Cronbach alpha coefficient was 0.87 , self-actualisation was 0.63 , job opportunities 
Creative commons User License: CC BY-NC-ND

Abstracted by: EBSCOhost, Electronic Journals Service (EJS),

Google Scholar, Directory of Open Access Journals (DOAJ),

Journal Seek, Scientific Commons,

Food and Agricultural Organization (FAO), CABI and Scopus
Journal of Agricultural Extension

Vol. XX (X) XXXXXX, 20XX

ISSN(e): 24086851; ISSN(Print); 1119944X

http://journal.aesonnigeria.org

http://www.ajol.info/index.php/jae

Email: editorinchief@aesonnigeria.org

(0.75), field attractiveness (0.73), ease of study (0.62) and scholastic achievement (0.67). Data were analysed with T-Test, analysis of variance (ANOVA) and Pearson's correlation.

\section{Results and Discussion}

\section{Profiles of the Respondents}

A large percentage of respondents (58.3\%) were in the age group of 21-25 years with a mean of 22.2 years and median of 22 years; the median age was thus higher than the national estimated median age of $18.2 \%$ for Nigeria (CIA World Factbook, 2016). Also, $50.6 \%$ were male while $49.4 \%$ were female. This could be a factor of enrolment of more males in science and technology courses than females. Aderemi et al. (2013) also observed that the number of female students admitted for science and technology courses was consistently lower than that of male counterparts. This is inconsistent with the findings of Lee et al. (2008) in their studies of hospitality and tourism management (HTM) in Hong Kong where they observed that female were more in overall undergraduate population than male. In addition, 19.9\% and 19.2\% were in 300 and 400 levels, respectively (Table 1).

\section{Table 1: Respondents' profile}

\begin{tabular}{ll}
\hline Variable & Percentage \\
\hline Age & \\
$16-20$ & 28.9 \\
$21-25$ & 58.3 \\
$26-30$ & 12.8 \\
Mean= 22.2, Median= 22 & \\
Sex & \\
Male & 50.6 \\
Female & 49.4 \\
Level of Study & \\
100 & 14.1 \\
200 & 17.9 \\
300 & 19.2 \\
400 & 19.9 \\
500 & 12.8 \\
Graduating & 16.0 \\
\hline
\end{tabular}


Creative commons User License: CC BY-NC-ND

Abstracted by: EBSCOhost, Electronic Journals Service (EJS), Google Scholar, Directory of Open Access Journals (DOAJ), Journal Seek, Scientific Commons,

Food and Agricultural Organization (FAO), CABI and Scopus
Journal of Agricultural Extension

Vol. XX (X) XXXXXX, 20XX

ISSN(e): 24086851; ISSN(Print); 1119944X

http://journal.aesonnigeria.org

http://www.ajol.info/index.php/jae

Email: editorinchief@aesonnigeria.org

\section{Students' Preferred Areas of Specialisation}

The results show that $74.4 \%$ and $25.6 \%$ preferred ecotourism management (EM) and wildlife (WM) management as the preferred areas of specialisation, respectively (Figure 2). That the majority of the students preferred ecotourism management could be due to the perception of students on the related nature of ecotourism to tourism and thus could provide them job opportunity in the tourism sector. Contrary to expectation, no gender differences were observed in specialisation preferences by the students ( $t=1.96, p \geq 0.05)$; although the mean of the male group was higher than that of the female group (Table 2). This confirmed the findings of Diderichsen et al. (2013) that showed almost no gender differences in students' specialties choices. Soethout et al. (2004) however reported gender differences in specialty career choices. Bhat et al. (2012) and Gjerberg (2001) observed that gender significantly influenced specialty choice.

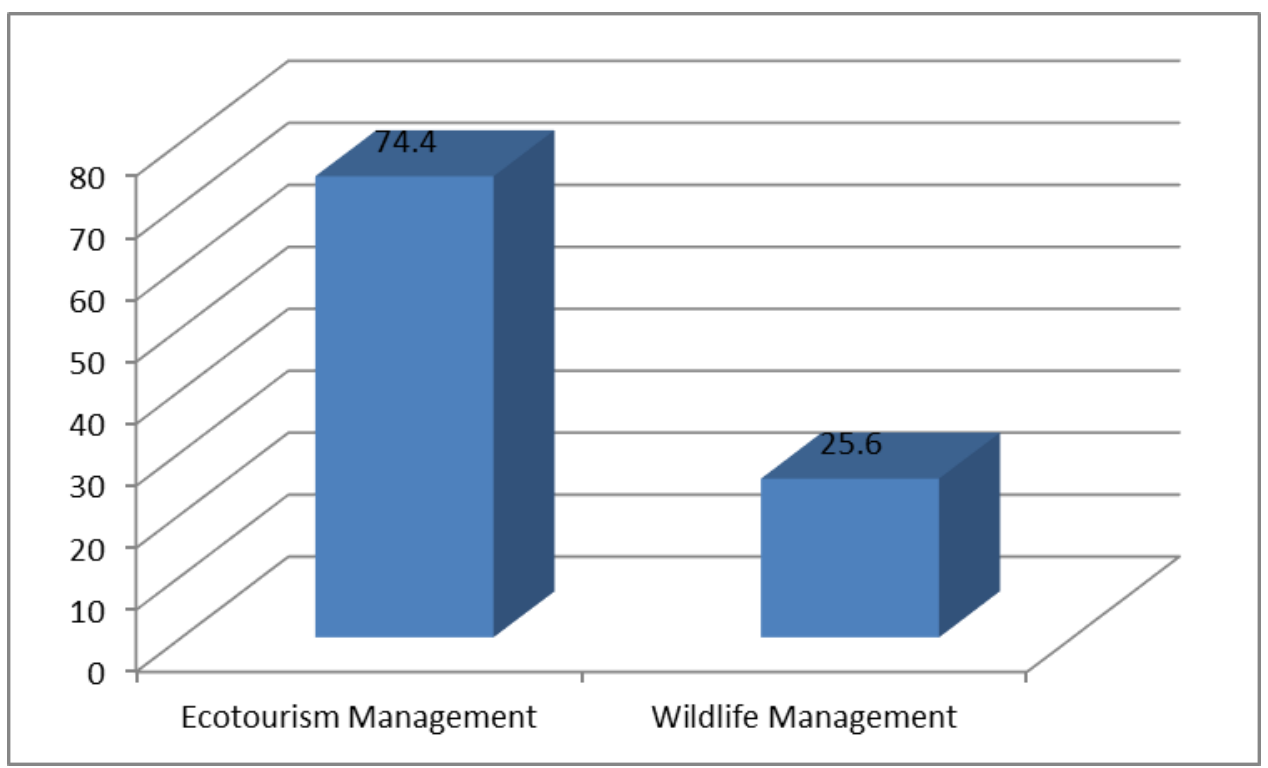

Figure 2: Respondents' preferred areas of specialisation (\%) 
Creative commons User License: CC BY-NC-ND

Abstracted by: EBSCOhost, Electronic Journals Service (EJS),

Google Scholar, Directory of Open Access Journals (DOAJ),

Journal Seek, Scientific Commons,

Food and Agricultural Organization (FAO), CABI and Scopus
Journal of Agricultural Extension

Vol. XX (X) XXXXXX, 20XX

ISSN(e): 24086851; ISSN(Print); 1119944X

http://journal.aesonnigeria.org

http://www.ajol.info/index.php/jae

Email: editorinchief@aesonnigeria.org

Table 2: Gender differences in students' preferred areas of specialisation

\begin{tabular}{|c|c|c|c|c|}
\hline Variable & $\begin{array}{l}\text { Male } \\
\text { (Mean) }\end{array}$ & $\begin{array}{l}\text { Female } \\
\text { (Mean) }\end{array}$ & $\begin{array}{l}\text { Mean } \\
\text { Difference }\end{array}$ & T-value \\
\hline $\begin{array}{l}\text { Preferred Area } \\
\text { of } \\
\text { Specialisation }\end{array}$ & 1.32 & 1.18 & 0.14 & $1.96^{*}$ \\
\hline
\end{tabular}

\section{Students' Motivational Factors}

Table 3 presents students' ratings of motivational factors for the area of specialisation preferences. For self-actualisation items, the means ranged from 3.71 to 4.48 with the highest mean value for possible contact with foreigners and foreign cultures. For job opportunity items; they ranged from 3.43 to 4.51 . The highest mean value was for "I believe that the field is practical rather than theoretical". Similarly, the means for field attractiveness items ranged from 3.37 to 4.47 with I believe that there are many opportunities to take more overseas trips having the highest means. For ease of study, they range from 2.72 to 3.95 with the score for university entrance examination qualified them for this major having highest mean score while the mean for scholastic achievement items ranges from 3.70 to 4.31 with the likeness to be an excellent scholar in this field having the highest mean score.

The findings on motivational factors imply that the students' motivational factors for their preferred areas of specialisation were lower than the observations of Lee et al. (2008) who reported that the mean of self-actualisation was from 4.62 to 5.35 , job opportunity from 4.65 to 5.37 , field attractiveness from 4.20 to 4.75 , ease of study from 4.09 to 4.61 while scholastic achievement were from 3.96 to 4.80 . Although job opportunity had the highest overall mean among the motivational factors (5.01) in Lee et al. (2008), the present findings showed that self-actualisation (4.20) had the highest overall mean. Tijani and Omirin (2013) also observed that personal and professional interest (an item under self-actualisation) was the major motivational factor for the choice of course of study. In addition, ease of study had the lowest overall mean in the present study as well as in Lee et al. (2008); the mean value obtained by Lee et al. (2008) (4.36) was higher than what was observed in this study 
Creative commons User License: CC BY-NC-ND

Abstracted by: EBSCOhost, Electronic Journals Service (EJS), Google Scholar, Directory of Open Access Journals (DOAJ), Journal Seek, Scientific Commons,

Food and Agricultural Organization (FAO), CABI and Scopus

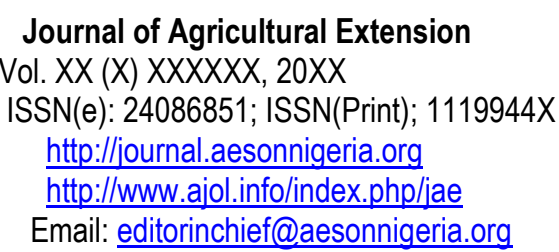

(3.55). These findings could suggest that students in hospitality and tourism management studied by Lee et al. (2008) had higher study motivations than students of ecotourism and wildlife management (EWM) that were the focus of this study. This could be as a result of the fact that few students actually selected EWM as a course of study in their JAMB forms but were offered admission to the course due to their inability to meet the aggregate scores and cut off marks for the courses they had interest in studying and selected for UTME, Post UTME and pre-degree examination conducted by the university. 
Creative commons User License: CC BY-NC-ND

Abstracted by: EBSCOhost, Electronic Journals Service (EJS),

Google Scholar, Directory of Open Access Journals (DOAJ),

Journal Seek, Scientific Commons,

Food and Agricultural Organization (FAO), CABI and Scopus
Journal of Agricultural Extension

Vol. XX (X) XXXXXX, 20XX

ISSN(e): 24086851; ISSN(Print); 1119944X

http://journal.aesonnigeria.org

http://www.ajol.info/index.php/jae

Email: editorinchief@aesonnigeria.org

Table 3: Students' ratings of motivational items

\begin{tabular}{|c|c|c|}
\hline Motivational items & Mean & $\begin{array}{l}\text { Standard } \\
\text { Deviation }\end{array}$ \\
\hline \multicolumn{3}{|l|}{ Self-actualisation } \\
\hline I have interest in the course & 4.24 & 0.72 \\
\hline $\begin{array}{l}\text { I would like to gain self-actualisation (i.e. to develop and achieve } \\
\text { one's full potential) }\end{array}$ & 4.37 & 0.80 \\
\hline This field suits my aptitude (i.e. talent and ability) & 3.71 & 1.05 \\
\hline $\begin{array}{l}\text { Compared to other fields, it is possible to contact foreigners and } \\
\text { foreign cultures }\end{array}$ & 4.48 & 0.70 \\
\hline Overall self-actualisation mean score & 4.20 & \\
\hline \multicolumn{3}{|l|}{ Job opportunity } \\
\hline I believe that this field has a growing potential & 4.28 & 0.85 \\
\hline $\begin{array}{l}\text { I believe that the percentage of employment is } \\
\text { high after graduation }\end{array}$ & 3.43 & 1.00 \\
\hline Working in this field apparently looks good & 3.96 & 0.81 \\
\hline $\begin{array}{l}\text { Scenes or pictures of the ecotourism and wildlife industry appearing } \\
\text { in movies/TV look attractive }\end{array}$ & 4.44 & 0.81 \\
\hline I believe that there are a variety of job opportunities & 3.85 & 1.00 \\
\hline I believe that this field is practical rather than theoretical & 4.51 & 0.77 \\
\hline Overall job opportunity mean score & 4.08 & \\
\hline \multicolumn{3}{|l|}{ Field Attractiveness } \\
\hline I like to serve others & 3.63 & 1.17 \\
\hline Jobs in this field look attractive & 3.97 & 0.92 \\
\hline I would like to study more in this field & 3.97 & 0.97 \\
\hline I believe that the level of salary is high in this field & 3.37 & 1.05 \\
\hline $\begin{array}{l}\text { I believe that I can have many opportunities to take more overseas } \\
\text { trips }\end{array}$ & 4.47 & 0.67 \\
\hline Overall field attractiveness mean score & 3.88 & \\
\hline \multicolumn{3}{|l|}{ Ease of Study } \\
\hline Compared to other fields, it is easier to get good grades in this field & 3.60 & 1.02 \\
\hline $\begin{array}{l}\text { This field was recommended by others (e.g., parents, friends or } \\
\text { teachers) }\end{array}$ & 2.72 & 1.40 \\
\hline My score for university entrance exam qualified me for this major & 3.95 & 1.23 \\
\hline Compared to other fields, it is easy to study field & 3.71 & 0.97 \\
\hline $\begin{array}{l}\text { Compared to other fields, this field provides } \\
\text { more opportunity to be promoted }\end{array}$ & 3.78 & 0.93 \\
\hline Overall ease of study mean score & 3.55 & \\
\hline \multicolumn{3}{|l|}{ Scholastic Achievement } \\
\hline I would like to be a theoretical expert in this field & 3.70 & 1.19 \\
\hline I have more interest in this field, compared to others & 3.78 & 1.07 \\
\hline I would like to be an excellent scholar in this field & 4.31 & 0.88 \\
\hline Overall scholastic achievement mean score & 3.93 & \\
\hline
\end{tabular}


Creative commons User License: CC BY-NC-ND

Abstracted by: EBSCOhost, Electronic Journals Service (EJS),

Google Scholar, Directory of Open Access Journals (DOAJ),

Journal Seek, Scientific Commons,

Food and Agricultural Organization (FAO), CABI and Scopus
Journal of Agricultural Extension

Vol. XX (X) XXXXXX, 20XX

ISSN(e): 24086851; ISSN(Print); 1119944X

http://journal.aesonnigeria.org

http://www.ajol.info/index.php/jae

Email: editorinchief@aesonnigeria.org

\section{Differences in Motivational Factors based on Students' Gender}

No significant difference was also observed between male and female students' motivational factors $(p \geq 0.05)$. Females, however, exhibited higher study motivation in all the motivational factors than male (Table 4). This confirmed the observations of Lee et al. (2008) that no significant differences exist between male and female motivational factors. Diderichsen et al. (2013) found that men and women had an almost identical ranking order of the motivational factors. Consistent with previous findings (Lee et al., 2008), female students exhibited higher study motivation in all the motivational factors than male. Kim et al. (2007) found female student's dominance in hospitality and tourism management study motivation in Korea, Taiwan and China.

Table 4: Gender differences in students' motivational factors

\begin{tabular}{lllll}
\hline Motivational factors & $\begin{array}{l}\text { Male } \\
\text { (Mean) }\end{array}$ & $\begin{array}{l}\text { Female } \\
\text { (Mean) }\end{array}$ & $\begin{array}{l}\text { Mean } \\
\text { Difference }\end{array}$ & T-value \\
\hline Self-actualisation & 16.56 & 17.05 & 0.50 & $1.37^{*}$ \\
Job opportunity & 24.09 & 24.87 & 0.78 & $1.40^{\star}$ \\
Field attractiveness & 19.03 & 19.79 & 0.77 & $1.43^{*}$ \\
Ease of study & 17.34 & 18.18 & 0.84 & $1.49^{*}$ \\
Scholastic achievement & 11.46 & 12.13 & 0.67 & $1.73^{*}$
\end{tabular}

${ }^{*} \mathrm{P} \geq 0.05$

\section{Differences in Motivational Factors based on Preferred Areas of Specialisation}

In Table 5, differences in motivational factors based on preferred areas of specialisation are presented. No significant differences were also observed in the students' motivational factors based on their preferred areas of specialisation ( $p$ 20.05). However, students exhibited slightly higher study motivation in ecotourism management regarding the job opportunity, field attractiveness and ease of study while they exhibited higher study motivation in wildlife management on selfactualisation and scholastic achievement. This is inconsistent with the observations of de Souza et al. (2015) that factors that influenced the intention of choice of specialties were different according to groups of specialties suggesting different motivational profiles. Kim et al. (2002) found the primary reasons to be interested in 
Creative commons User License: CC BY-NC-ND

Abstracted by: EBSCOhost, Electronic Journals Service (EJS),

Google Scholar, Directory of Open Access Journals (DOAJ),

Journal Seek, Scientific Commons,

Food and Agricultural Organization (FAO), CABI and Scopus
Journal of Agricultural Extension

Vol. XX (X) XXXXXX, 20XX

ISSN(e): 24086851; ISSN(Print); 1119944X

http://journal.aesonnigeria.org

http://www.ajol.info/index.php/jae

Email: editorinchief@aesonnigeria.org

the type of work associated with their specialisation, good job opportunities, and a good match with their capabilities and future earnings. Huyton (1997) observed abundant job opportunities as the major motive for hospitality and tourism management (HTM) programmes. In the comparison of Greek and UK students, Airey and Frontistis (1997) found that Greek students had a more positive view of job opportunities in the hospitality and tourism industry than their UK counterparts.

Table 5: Differences in motivational factors based on preferred areas of specialisation

\begin{tabular}{lllll}
\hline Variable & Ecotourism & Wildlife & Mean & T value \\
& Management & Management & Difference &
\end{tabular}

\begin{tabular}{lllll}
\hline Self-actualisation & 16.77 & 16.90 & -0.13 & $-0.31^{*}$ \\
Job opportunity & 24.50 & 24.41 & 0.09 & $0.13^{*}$ \\
Field attractiveness & 19.56 & 18.92 & 0.64 & $1.03^{*}$ \\
Ease of study & 17.86 & 17.44 & 0.43 & $0.65^{*}$ \\
Scholastic & 11.65 & 12.21 & -0.56 & $-1.23^{*}$
\end{tabular}

achievement

${ }^{*} \mathrm{P} \geq 0.05$

\section{Differences in Motivational Factors based on Level of Study}

Differences in students' motivational factors based on students' level of study are presented in Table 6. No significance difference was observed in self-actualisation $(F=1.13, p \geq 0.05)$, field attractiveness $(F=2.21, p \geq 0.05)$, easy of study $(F=2.19, p$ $\geq 0.05)$, and scholastic achievement $(F=1.27, p \geq 0.05)$, however, there was significant difference in job opportunity ( $F=5.52, \quad p \leq 0.01)$. This could imply that students at different levels of study in ecotourism and wildlife management have different perceptions of the ability of the course to provide them with the needed job after graduation. 
Creative commons User License: CC BY-NC-ND

Abstracted by: EBSCOhost, Electronic Journals Service (EJS),

Google Scholar, Directory of Open Access Journals (DOAJ),

Journal Seek, Scientific Commons,

Food and Agricultural Organization (FAO), CABI and Scopus
Journal of Agricultural Extension

Vol. XX (X) XXXXXX, 20XX

ISSN(e): 24086851; ISSN(Print); 1119944X

http://journal.aesonnigeria.org

http://www.ajol.info/index.php/jae

Email: editorinchief@aesonnigeria.org

Table 6: Differences in motivation factors based on students' level of study

\begin{tabular}{ll}
\hline Variable & $\mathrm{F}$ \\
\hline Self-actualisation & 1.13 \\
Job opportunity & $5.52^{\star \star}$ \\
Field attractiveness & 2.21 \\
Ease of study & 2.19 \\
Scholastic achievement & 1.27 \\
\hline
\end{tabular}

${ }^{\star *} P \leq 0.01$

\section{Relationship between Motivational Factors and Students' Areas of Specialisation}

In Table 7, the relationship between motivational factors and students' areas of specialisation preference is presented. No statistically significant relationship was observed between motivational factors and students' preferred areas of specialisation $(p \geq 0.05$ ). This could be due to the nature of their admission to the programme since most of them did not choose the course as their preferred course of study at the point of admission into the university. Thus, most of the students were actually offered admission into the course because they didn't qualify for their preferred courses and their scores qualified them for the course. In addition, some of them changed their academic programme to Ecotourism and Wildlife Management Programme due to their inability to cope with the initial courses they were admitted to study at the University. It could thus be deduced that students had lower motivations in EWM Programme.

Table 7: Relationship between motivational factors and students' preferred areas of specialisation

\begin{tabular}{lll}
\hline Variable & Correlation Value $(r)$ & $\mathrm{P}$ Value \\
\hline Self-actualisation & 0.03 & $0.76^{*}$ \\
Job opportunity & -0.01 & $0.90^{\star}$ \\
Field attractiveness & -0.08 & $0.31^{*}$ \\
Ease of study & -0.05 & $0.51^{*}$ \\
Scholastic achievement & 0.10 & $0.22^{*}$ \\
\hline
\end{tabular}

${ }^{*} \mathrm{P} \geq 0.05$ 
Creative commons User License: CC BY-NC-ND

Abstracted by: EBSCOhost, Electronic Journals Service (EJS), Google Scholar, Directory of Open Access Journals (DOAJ), Journal Seek, Scientific Commons,

Food and Agricultural Organization (FAO), CABI and Scopus
Journal of Agricultural Extension

Vol. XX (X) XXXXXX, 20XX

ISSN(e): 24086851; ISSN(Print); 1119944X

http://journal.aesonnigeria.org

http://www.ajol.info/index.php/jae

Email: editorinchief@aesonnigeria.org

\section{Conclusion and Recommendations}

The majority of respondents preferred ecotourism management to wildlife management. This could be due to the perception of students on the related nature of ecotourism to tourism and thus could provide them job opportunity in the tourism sector. Opportunities for study exchange programme with institutions offering similar programmes overseas that could enable the students have contact with foreigners and foreign cultures as well as making overseas trips should be provided in the development of course curriculum for the department. In addition, field practical exposure in all areas of the programme that could bolster students' job opportunities after graduation and make them excellent scholars in the field should be accorded priority in the delivery of the curriculum. These are necessary in view of the peculiarities of their admission into the department.

\section{References}

Aderemi, H.O., Hassan, O.M., Sinyanbola, W.O. and Taiwo, K. (2013). Trends in enrolment, graduation and staffing of science and technology education in Nigeria tertiary institutions: A gender participation perspective. Education Research and Reviews, 8(21): 2011- 2020

Airey, D., and Frontistis, A. (1997). Attitudes to careers in tourism: An Anglo Greek comparison. Tourism Management, 18(3): 149-158.

Ajzen, I. and Fishein, M. (1969). The prediction of behavioral intentions in a choice situation. Journal of Experimental Social Psychology, 5: $\quad$ 400-416.

Ajzen, I. and Fishein, M. (1980). Understanding attitudes and predicting social behaviour, Prentice-Hall: Englewood Cliffs, NJ.

Ajzen, I. (1991). The theory of planned behavior. The Organizational Behavior and Human Decision Processes, 50(2): 179-211.

Ajzen, I. (2006). Constructing a theory of planned behavior questionnaire. Accessed from http://people.umass.edu/aizen/pdf/tpb.measurement.pdf.

Amani, J. (2013). Social influence and occupational knowledge as predictors of career choice intentions among undergraduate students in Tanzania. International Journal of Learning and Development, 3(3):185-193

Arnott, T. and Saunders, L. (eds.) (2008). Career choice: The voices of music students. African Minds, Centre for Indigenous Instrumental Music and Dance Practices of Africa. 135pp

Bhat, S., D'Souza, L. and Fernandez, J. (2012). Factors influencing the career choices of medical graduates. Journal of Clinical and Diagnostic Research, $6(1): 61-64$ 
Creative commons User License: CC BY-NC-ND

Abstracted by: EBSCOhost, Electronic Journals Service (EJS),

Google Scholar, Directory of Open Access Journals (DOAJ),

Journal Seek, Scientific Commons,

Food and Agricultural Organization (FAO), CABI and Scopus
Journal of Agricultural Extension

Vol. XX (X) XXXXXX, 20XX

ISSN(e): 24086851; ISSN(Print); 1119944X

http://journal.aesonnigeria.org

http://www.ajol.info/index.php/jae

Email: editorinchief@aesonnigeria.org

Bamford, K.L. (2012). Undergraduate student perceptions of a career in the tourism and hospitality industry in New Zealand. Masters' Thesis, University of Otago, Dunedin, New Zealand. 158pp

Central Intelligence Agency (CIA) Factbook (2016) The World Factbook Africa: Nigeria. Retrieved from https://www.cia.gov/library/publications/the-worldfactbook/geos/ni.html

Cronbach, L.J. (1951). Coefficient alpha and internal structure of tests. Psychometrica, 16: 297-334

Dapiawen, A.A., Dicang, M.D. and Tique, R.C. (2008). Motivating factors and field of specialisation preferences of the UB College of Education students. UB RJ, XXXII (1)

de Souza, L.C.L., Mendonça, V.R.R., Garcia, G.B.C., Brandão, E.C., and Barral-Netto, M. (2015) Medical specialty choice and related factors of Brazilian medical students and recent doctors. PLOS ONE, 10(7): e0133585. doi:10.1371/journal.pone.0133585

Diderichsen, S., Johansson, E.E., Verdonk, P., Lagro-Janssesn, T. and Hamberg, K. (2013). Few gender differences in specialty preferences and motivational factors: a cross-sectional Swedish study on last year medical students. BMC Medical Education, 13:39

Gjerberg, E. (2001). Medical women- towards full integration? An analysis of the specialty choices made by two cohorts of Norwegian doctors. Soc. Sci Med., 52:3

Hjalager, A. (2003). Global tourism careers? Opportunities and dilemmas facing higher education in tourism. Journal of Hospitality, Leisure, Sport and Tourism Education, 2(2), 26-37.

Huyton, J. R. (1997). The implications of cross-cultural communication in the hotel industry: A Chinese case. Proceedings of the 7th National Tourism and Hospitality Research Conference, Sydney: Bureau of Tourism Research.

Kim, D., Markham, F. S., and Cangelosi, J. D. (2002). Why students pursue the business degree: A comparison of business majors across universities. Journal of Education for Business, 78, 28-32. doi:10.1080/08832320209599694

Kim, S., Guo, Y., Wang, K., and Agrusa, J. (2007). The study motivations and study preferences of student groups from Asian nations majoring in hospitality and tourism management programs. Tourism Management, 28(1), 140-151.

Krejcie, R.J. and Morgan, D.W. (1970). Determining sample size for research activities. Educational and Psychological Measurement, 30: 607-610

Lee, M.J., Kim, S.S., and Lo, A. (2008). Perceptions of hospitality and tourism students towards study motivations and preferences: a study of Hong Kong students. Journal of Hospitality, Leisure, Sport and Tourism Education, $7(2): 45-58$

Meyer, J.P., Allen, N.J., Smith, C.A., (1993). Commitment to organizations and occupations: Extension and test of a three-component conceptualization. Journal of Applied Psychology, 78, 538-551. 
Creative commons User License: CC BY-NC-ND

Abstracted by: EBSCOhost, Electronic Journals Service (EJS),

Google Scholar, Directory of Open Access Journals (DOAJ),

Journal Seek, Scientific Commons,

Food and Agricultural Organization (FAO), CABI and Scopus
Journal of Agricultural Extension

Vol. XX (X) XXXXXX, 20XX

ISSN(e): 24086851; ISSN(Print); 1119944X

http://journal.aesonnigeria.org

http://www.ajol.info/index.php/jae

Email: editorinchief@aesonnigeria.org

Natan, M.B. and Becker, F. (2010). Israelis' perceived motivation for choosing a nursing career. Nurse Education Today, 30:308-313.

Nzewi, M. (2008). Forewords. In: Arnott, T. and Saunders, L. (eds.) 2008. Career choice: The voices of music students. African Minds, Centre for Indigenous Instrumental Music and Dance Practices of Africa. 135pp

Orenuga O., and Costa, O. (2006), Characteristics and study motivation of clinical dental students in Nigerian Universities. Journal of Dental Education, 70(9): 996-1003.

Romeo, C. (2014). Predisposition factors of students' choice in Agriculture, Fisheries and Natural Resources (AFNR) courses (Luzon Area). Asia Pacific Journal of Multidisciplinary Research, 2(1):170-177.

Santos, J.R.A. (1999). Cronbach's alpha: A tool for assessing the reliability of scales. Journal of Extension, 37(2): 1-6

Sibson, R. (2011). Career choice perceptions of undergraduate event, sport and recreation management students: An Australian case study. Journal of Hospitality, Leisure, Sport and Tourism Education, 10(2):50-60.

Soethout, M.B.M., tenCate, TH.J. and vander Wal, G. (2004). Factors associated with nature, timing and stability of the specialty career choices of recently graduated doctors in European countries, a literature review. Med Educ Online, 9:24

Tijani, S.A. and Omirin, T.I. (2013). Perception of agricultural extension as a career among postgraduate students of agriculture in selected universities in Southwest, Nigeria. Journal of Agricultural Extension, 17(2): 149-158

Ugezu, A.I. and Modekwe, V.I. (2012). House officers' choice of speciality in Nnewi, South East, Nigeria. AFRIMEDIC Journal, 3(1):16-21.

University of Agriculture, Abeokuta- Institute of Food Security, Environmental Resources and Agricultural Research (UNAAB-IFSERAR) (2010). $171 \mathrm{pp}$

Wairimu, J.W. (2013). Factors influencing the choice of specialisation of MBA courses by students at institutions of higher learning in Kenya: A survey of Nyeri County. Masters' Thesis, Kenyatta University. 45pp.

Wong, R., Fiedler, A., and Liu, C. (2007). Exploring the motivation of students in choosing information systems as their major. Issues in Information Systems, 53(1), 198-203.

Zahari, M.S., Sharif, M.S. and Ismail, T.A.T. (2005). A study of factors moderating students' selection of hospitality programme and subsequent career intentions. TEAM Journal of Hospitality and Tourism, 2(1):103-124 